\title{
HUBUNGAN FREKUENSI MINUM SOFT DRINK TERHADAP pH SALIVA DAN ANGKA DMF-T PADA SISWA/I KELAS XI IPA MAN 2 MODEL JALAN WILLIEM ISKANDAR NO. 7A KEC. MEDAN TEMBUNG TAHUN 2014
}

\author{
Intan Aritonang \\ Jurusan Keperawatan Gigi Poltekkes Kemenkes Medan
}

\begin{abstract}
Abstrak
Soft drink adalah minuman ringan yang mengandung karbonasi yang dapat menurunkan $\mathrm{pH}$ saliva,yaitu keadaan saliva menjadi asam, dan hal ini dapat membuat gigi jadi lebih rentan menjadi karies, dan jika frekuensi minum tinggi maka keadaan saliva lebih sering dalam keadaan asam. Jenis penelitian adalah penelitian analitik dengan uji korelasi persen suatu penelitian untuk mengetahui hubungan antara frekuensi meminum soft drink terhadap $\mathrm{pH}$ saliva dan hubungan antara frekuensi soft drink dengan angka DMF-T. dengan cara pemeriksaan terhadap pH saliva dan angka DMF-T. penelitia ingin mengetahui pengaruh frekuensi minum soft drink terhadap $\mathrm{pH}$ saliva dan angka DMFT pada siswa/I kelas XI ipa Man 2 Model Medan. Dari 32 siswa yang memiliki pH 4 ada 7 orang, 5 ada 19 orang dan 6 ada 6 orang, dan frekuensi minum dalam 1 minggu 0 dalam 1 minggu 3 orang, 1 kali seminggu 3 orang, 2 kali seminggu 11 orang, 3 kali seminggu 2 orang, 4 kali seminggu 1 orang, 5 kali seminggu 6 orang, 6 kali seminggu 2 orang, 8 kali seminggu 2 0rang, 9 kali seminggu 2 orang. Penelitian tentang pengaruh mengkonsumsi soft drink terhadap $\mathrm{pH}$ saliva dan angka DMF-T pada siswa/I kelas XI IPA MAN 2 Model Medan adalah semakin banyak frekuensi minum soft drink maka semakin rendah angka $\mathrm{pH}$ saliva dan semakin tinggi frekuensi minum soft drink maka semakin rendah angka DMF-T di dukung dengan kebiasaan siswa/I yang meminum soft drink pada istirahat atau bersantai, dan tidak berkumur-kumur setelah minum soft drink tersebut.
\end{abstract}

Kata kunci: Soft drink, pH Saliva, DMF-T

\section{PENDAHULUAN}

Pengertian kesehatan Kesehatan Dunia WHO pada Piagam Ottawa yang didedikasikan untuk promosi kesehatan pada tahun 1986.Pada saat itu, Organisasi Kesehatan Dunia (WHO) tersebut menyatakan bahwa kesehatan bukan tujuan dari hidup melainkan sumber daya untuk hidup sehari-hari.Selain itu, kesehatan dikatakan juga sebagai suatu konsep yang positif dan terfokus pada kemampuan fisik.Kemudian pengertian kesehatan juga merupakan suatu keadaan atau kondisi dari jiwa dan raga serta juga sosial yang dapat menjadikan seseorang dengan kehidupannya yang produktif baik dari segi ekonomi maupun dari segi kehidupan sosialnya.

Pepkins mendefinisikan sehat sebagai keadaan keseimbangan yang dinamis dari badan dan fungsifungsinya sebagai hasil penyesuaian yang dinamis terhadap kekuatan-kekuatan yang cenderung menggangunya.Badan seseorang bekerja secara aktif untuk mempertahankan diri agar tetap sehat sehingga kesehatan selalu harus dipertahankan.
Kesehatan gigi dan mulut merupakan komponen dari kesehatan umum yang berperan penting dalam fungsi pengunyahan, fungsi bicara, dan fungsi kecantikan.Ketiga fungsi tersebut sangat penting dalam menunjang tumbuh kembang anak. Hasil Riset Kesehatan Dasar Nasional (Riskesdas) tahun 2007 menyebutkan bahwa 23,4\% penduduk Indonesia mempunyai masalah kesehatan gigi dan mulut dan hanya $29,6 \%$ penduduk diantaranya yang menerima perawatan dan pengobatan dari tenaga kesehatan gigi. Hal ini mengindikasikan bahwa masih terdapat masyarakat yang belum menyadari pentingnya pemeliharaan kesehatan gigi dan mulut. Penyakit gigi dan mulut yang ditemukan di masyarakat masih berkisar penyakit yang menyerang jaringan keras gigi (karies) dengan Indeks DMF-T nasional sebesar 4,85 (Dep. Kes. RI., 2008).

Menurut Undang-undang RI No.36 tahun 2009 tentang kesehatan, menjelaskan bahwa pelayanan kesehatan gigi dan mulut adalah upaya kesehatan dengan pendekatan pemeliharaan, peningkatan kesehatan (promotif), pencegahan penyakit (preventif), pengobatan penyakit (kuratif) dan pemulihan kesehatan (rehabilitatif). Program ini dilaksanakan secara terencana, menyeluruh, 
terpadu dan berkesinambungan, ditujukan pada kelompok tertentu yang dapat diikuti dalam suatu kurun waktu tertentu, untuk mencapai tujuan "kesehatan gigi dan mulut yang optimal" (UU RI., 2009).

Konsumsi per kapita tahun 2011 hanya 2,4 liter per tahun," kata Sekretaris Jenderal ASRIM, Suroso Natakusuma, dalam konferensi pers di gedung World Trade Center, Senin, 17 Desember 2012. Ia mengatakan tingkat konsumsi tersebut masih lebih rendah dibandingkan dengan di negara-negara lain. Konsumsi di Filipina mencapai 34,1 liter per kapita dan Malaysia sebanyak 19 liter per kapita per tahun.

Salah satu faktor penyebab karies Keadaan gigi Untuk tejadinya karies gigi antara lain dibutuh tuan rumah (gigi) yang rentan, lapisan keras gigi terdiri dari enamel dan dentin, di mana enamel adalah lapisan yang paling luar dan seperti diketahui karies selalu di mulai dari lapisan luar.Keadaan salivaSaliva sangat mempengaruhi proses terjadinya karies, karena saliva selalu membasahi rongga mulut yang dapat mempengaruhi rongga mulut. Dimana makin rendah $\mathrm{pH}$ saliva maka karies cenderung semakin tinggi.

Masa remaja menurut Mappiare (1982), berlangsung antara umur 12 tahun sampai dengan 21 tahun bagi wanita dan 13 tahun sampai dengan 22 tahun bagi pria. Rentang usia ini dapat dibagi menjadi dua bagian yaitu usia 12/13 tahun sampai dengan 17/18 tahun adalah remaja awal, dan usia 17/18 tahun sampai dengan 21/22 tahun adalah remaja akhir. Menurut hokum di Amerika Serikat saat ini, individu dianggap telah dewasa apabila telah mencapai usia 18 tahun dan bukan 21 tahun seperti ketentuan sebelumnya (Hurlock, 1991). Pada usia ini umum nya anak sedang duduk dibangku Sekolah Menengah Atas (SMA).

Istilah pH merupakan symbol yang digunakan untuk menunjukkan tingkat keasaman atau kebasaan suatu larutan.Semua jenis larutan mengandung ion hidrogen dan hidroksil.Semakin banyak ion hydrogen, semakin asam larutan tersebut. Jika ion hidroksil melebihi ion hydrogen, larutan tersebut bersifat basa, namun bila jumlah kedua ion tersebut sama, larutan tersebut bersifat netral.(Purwiyatno, 2009).

Saliva atau ludah adalah cairan kental yang diproduksi oleh kelenjar ludah. Kelenjar-kelenjar ludah tersebut terletak dibawah lidah, daerah otot pipi dan daerah dekat langit-langit, air ludah 99\% terdiri dari air, sisanya bermacam-macam, ada zat-zat seperti kalsium (zat kapur), fosfor, natrium, magnesium dll, dan disamping itu terdapat enzim-enzim bahkan golongan darah, lemak, zat tepung, vitamin dan sebagainya.(Ircham Machfoedz,2008).

\section{Tujuan Penelitian}

Untuk mengetahui tentang hubungan frekuensi minum soft drink terhadap $\mathrm{pH}$ saliva dan angka DMF-T.

\footnotetext{
Manfaat Penelitian

diharapkan
}

1. Dapat menambah informasi tentang hubungan frekuensi minum soft drink dengan angka DMF-T.

2. Dapat menyediakan data dan informasi bagi peneliti yang sejenis selanjutnya.

\section{HIPOTESIS}

Ho : Tidak ada pengaruh minum soft drink dengan perubahan $\mathrm{pH}$ saliva dan angka DMF-T pada siswa/I Man 2 Model Medan

$\mathrm{Ha}$ : ada pengaruh minum soft drink dengan perubahan pH saliva dan angka DMF-T pada siswa/I Man 2 Model Medan

\section{METODE PENELITIAN}

\section{Jenis Penelitian}

Jenis penelitian adalah penelitian analitik dengan uji korelasi persen suatu penelitian untuk mengetahui hubungan antara frekuensi meminum soft drink terhadap $\mathrm{pH}$ saliva dan hubungan antara frekuensi soft drink dengan angka DMF-T. dengan cara pemeriksaan terhadap $\mathrm{pH}$ saliva dan angka DMF-T. penelitia ingin mengetahui pengaruh frekuensi minum soft drink terhadap $\mathrm{pH}$ saliva dan angka DMF-T pada siswa/I kelas XI ipa Man 2 Model Medan Jl.Williem Iskandar No 7A Kelurahan Siderejo KEC. Medan Tembung.

\section{Populasi dan Sampel penelitian}

Populasi adalah wilayah generalisasi yang terdiri dari subjek/objek yang mempunyai kualitas dan karakteristik tertentu yang di tetapkan oleh peneliti untuk dipelajari dan ditarik kesimpulannya(Sugiyono, 2009), siswa/i kelas XI IPA MAN 2 Model Medan.Populasi yang diambil dalam penelitian ini adalah siswa/I kelas XI ipa MAN 2 Model Medan sebanyak 212 siswa/i

Sampel adalah sebagian yang diambil dari populasi atau keseluruhan obyek yang diteliti dan dianggap mampu mewakili seluruh populasi

\section{Waktu Penelitian}

Penelitian ini dilakukan dari Bulan September Desember 2014

\section{HASIL DAN PEMBAHASAN}

\section{Hasil Penelitian}

Penelitian ini di lakukan pada 32 orang siswa/I kelas XI Ipa MAN 2 Model Medan Tahun 2014. Pengumpulan data ini dilakukan dengan cara pemeriksaan subjektif dengan wawancara pada siswa, dan pemeriksaan objektif atau pemeriksaan langsung ke rongga mulut siswa. Setelah data terkumpul, dimasukan ke dalam tabel distribusi frekuensi kemudian dilakukan analisa data dengan menggunakan program SPSS. Maka di dapat hasil sebagai berikut. 
TABEL A.1

Distribusi Frekuensi Siswa yang Meninum Soft Drink Di MAN 2 Model Medan Tahun 2014

No Frekuensi minum soft Jumlah Persentase
drink dalam 1 minggu siswa

\begin{tabular}{lccc}
\hline $\mathbf{1}$ & 0 & 3 & 9,4 \\
$\mathbf{2}$ & 1 & 3 & 9,4 \\
$\mathbf{3}$ & 2 & 11 & 34,4 \\
$\mathbf{4}$ & 3 & 2 & 6,3 \\
$\mathbf{5}$ & 4 & 1 & 3,1 \\
$\mathbf{6}$ & 5 & 6 & 18,8 \\
$\mathbf{7}$ & 6 & 2 & 6,3 \\
$\mathbf{8}$ & 8 & 2 & 6,3 \\
$\mathbf{9}$ & 9 & 2 & 6,3 \\
\hline & Jumlah & 32 & 100 \\
\hline
\end{tabular}

Dari tabel di atas dapat di lihat bahwa dari 32 orang siswa yang di teliti ada 3 orang $(9,4 \%)$ yang tidak pernah meminum soft drink, 3 orang $(9,4 \%)$ yang minum 1 kali seminggu, ada 11 orang $(34,4 \%)$ yang meminum soft drink 2 kali dalam seminggu, 2 orang $(6,3 \%)$ meminum soft drink 3 kali dalam seminggu, ada juga yang meminum soft drink 4 kali dalam seminggu sebanyak 1 orang $(3,1 \%)$, 6 orang $(18,8 \%)$ meminum soft drink 5 kali dalam seminggu, dan 2 orang meminum soft drink 6, 8 dan 9 kali dalam seminggu.

TABEL A.2

Distribusi Frekuensi pH Siswa yang Meninum Soft Drink Di MAN 2 Model Medan Tahun 2014

\begin{tabular}{cccc}
\hline No & pH & Jumlah Siswa & Persentase \\
\hline $\mathbf{1}$ & 4 & 7 & 21,9 \\
$\mathbf{2}$ & 5 & 19 & 59,4 \\
$\mathbf{3}$ & 6 & 6 & 18,8 \\
\hline & Jumlah & 32 & 100 \\
\hline
\end{tabular}

Dari tabel diatas dapat dilihat dari 32 siswa yang diteliti bahwa setelah meminum soft drink ada 7 orang $(21,9 \%)$ yang memiliki $\mathrm{pH} 4,19$ orang $(59,4 \%)$ memiliki $\mathrm{pH} 5$, dan 6 orang $(18,8 \%)$ yang memiliki $\mathrm{pH} 6$.

TABEL A.3

Distribusi Frekuensi DMF-T Siswa yang Meminum Soft Drink Di MAN 2 Model Medan Tahun 2014

\begin{tabular}{cccc}
\hline No & DMF-T & Jumlah siswa & Persentase \\
\hline $\mathbf{1}$ & 0 & 1 & 3,1 \\
$\mathbf{2}$ & 1 & 2 & 6,3 \\
$\mathbf{3}$ & 2 & 3 & 9,4 \\
$\mathbf{4}$ & 3 & 2 & 6,3 \\
$\mathbf{5}$ & 4 & 6 & 18,8 \\
$\mathbf{6}$ & 5 & 6 & 18,8 \\
$\mathbf{7}$ & 6 & 1 & 3,1 \\
$\mathbf{8}$ & 7 & 2 & 6,3 \\
$\mathbf{9}$ & 8 & 2 & 6,3 \\
$\mathbf{1 0}$ & 9 & 2 & 6,3 \\
$\mathbf{1 1}$ & 10 & 1 & 3,1 \\
$\mathbf{1 2}$ & 11 & 4 & 12,5 \\
\hline \multicolumn{5}{c}{ Jumlah } & 32 & 100 \\
\hline
\end{tabular}

Dari tabel diatas dapat dilihat bahwa dari 32 orang siswa yang diteliti ada 1 orang dengan DMF-T 0 atau bebas karies, 2 orang dengan DMF-T 1, 3 orang dengan DMF-T 2, 2 orang dengan DMF-T 3, 6 orang dengan DMF-T 4, 6 orang dengan DMF-T 5, 1 orang dengan DMF-T 6, 2 orang dengan DMF-T 7, 2 orang dengan DMF-T 8, 2 orang dengan DMF-T 9, 1 orang dengan DMF-T 10, dan 4 orang dengan DMF-T 11.

Dari data diatas maka didapat korelasi antara frekuensi minum soft drink terhadap $\mathrm{pH}$ saliva dan korelasi anatara frekuensi terhadap angka DMF-T.

TABEL A.4

Distribusi pengaruh Frekuensi pH Siswa yang Meninum Soft Drink tehadap pH Di MAN 2 Model Medan Tahun 2014

\begin{tabular}{cccc}
\hline No & pH & $\begin{array}{c}\text { Frekuensi minum } \\
\text { dalam satu minggu }\end{array}$ & Jumlah siswa \\
\hline $\mathbf{1}$ & 4 & $3-9$ kali & 7 \\
$\mathbf{2}$ & 5 & $2-5 \mathrm{kali}$ & 19 \\
$\mathbf{3}$ & 6 & $0-1 \mathrm{kali}$ & 6 \\
\hline & & 32 \\
\hline
\end{tabular}

TABEL A.5

Distribusi Frekuensi Hubungan DMF-T Ternadap Frekuensi Meminum Soft Drink Di MAN 2 Model Medan Tahun 2014

No DMF-T Jumlah siswa Frekuensi minum dalam satu minggu

\begin{tabular}{cccc}
\hline $\mathbf{1}$ & 0 & 1 & 0 kali \\
$\mathbf{2}$ & 1 & 2 & 0 kali \\
$\mathbf{3}$ & 2 & 3 & 1 kali \\
$\mathbf{4}$ & 3 & 2 & $2 \mathrm{kali}$ \\
$\mathbf{5}$ & 4 & 6 & $2-5 \mathrm{kali}$ \\
$\mathbf{6}$ & 5 & 6 & $2-5 \mathrm{kali}$ \\
$\mathbf{7}$ & 6 & 1 & $5 \mathrm{kali}$ \\
$\mathbf{8}$ & 7 & 2 & $5 \mathrm{kali}$ \\
$\mathbf{9}$ & 8 & 2 & $2-5 \mathrm{kali}$ \\
$\mathbf{1 0}$ & 9 & 2 & $6 \mathrm{kali}$ \\
$\mathbf{1 1}$ & 10 & 1 & $8 \mathrm{kali}$ \\
$\mathbf{1 2}$ & 11 & 4 & $8-9$ kali \\
\hline
\end{tabular}

\section{PEMBAHASAN}

Penelitian ini dilakukan pada 32 orang siswa/I kelas XI IPA MAN 2 Model Medan Tahun 2014 dan dilaksanakan dengan melakukan pemeriksaan subjektif dan objektif atau dengan melakukan wawancara dan pemeriksaan langsung ke rongga mulut siswa.

Dari tabel A.1. dapat diperoleh dari 23 orang siswa/I MAN 2 Medan terdapat 3 orang $(9,4 \%)$ yang tidak pernah meminum soft drink, 3 orang $(9,4 \%)$ yang minum 1 kali seminggu, ada 11 orang $(34,4 \%)$ yang meminum soft drink 2 kali dalam seminggu, 2 orang 
$(6,3 \%)$ meminum soft drink 3 kali dalam seminggu, ada juga yang meminum soft drink 4 kali dalam seminggu sebanyak 1 orang $(3,1 \%)$, 6 orang $(18,8 \%)$ meminum soft drink 5 kali dalam seminggu, dan 2 orang meminum soft drink 6,8 dan 9 kali dalam seminggu. Dari tabel A.2 juga dapat dilihat bahwa setelah meminum soft drink ada 7 orang $(21,9 \%)$ yang memiliki pH 4, 19 orang $(59,4 \%)$ memiliki $\mathrm{pH} 5$, dan 6 orang $(18,8 \%)$ yang memiliki $\mathrm{pH}$ 6. Maka semakin besar frekuensi atau sering meminum soft drink maka $\mathrm{pH}$ saliva semakin asam atau rendah.

Dengan melalui uji korelasi maka didapat data yang signifikan, dengan korelasi yang kuat yaitu 0,91.Penurunan $\mathrm{pH}$ saliva ini dikarenakan minuman ringan bersifat asam dan memiliki pH 3.0 atau lebih rendah yang dapat menyebabkan demineralisasi pada jaringan keras gigi.pH saliva akan kembali pada keadaan normal dalam waktu 30 detik setelah terpapar oleh minuman ringan.Konsumsi minuman ringan pada remaja (usia 8-17 tahun) dapat menyebabkan resiko yang tinggi terhadap terjadinya karies dan erosi gigi karena enamel gigi pada anak remaja belum terlalu matang dan struktur enamelnya cenderung poreus, konsistensinya seperti kapur dan mudah dipenetrasi dan dilarutkan oleh asam yang terkandung dalam minuman ringan.Minuman ringan dapat mengakibatkan erosi gigi pada waktu kritis yaitu pada menit pertama setelah terpaparnya rongga mulut denganminuman ringan. Proses erosi yang terjadi pada gigi diakibatkan oleh $\mathrm{pH}$ minuman ringanyang asam. Kondisi yang tidak menguntungkan ini, akan dikompensasi oleh protein saliva yang akan mengurangi kesempatan terjadinya erosi gigi.

Dari tabel A.3 ada 1 orang dengan DMF-T 0 atau bebas karies, 2 orang dengan DMF-T 1, 3 orang dengan DMF-T 2, 2 orang dengan DMF-T 3, 6 orang dengan DMF-T 4, 6 orang dengan DMF-T 5, 1 orang dengan DMF-T 6, 2 orang dengan DMF-T 7, 2 orang dengan DMF-T 8, 2 orang dengan DMF-T 9, 1 orang dengan DMF-T 10, dan 4 orang dengan DMF-T 11. Maka semakin rendah $\mathrm{pH}$ saliva maka semakin tinggi angka DMF-T.

Derajat keasaman $(\mathrm{pH})$ pada minuman-minuman bersoda seperti Pepsi Cola dan Coca Cola mencapai 3-4 (sangat asam), yang dengan $\mathrm{pH}$ tersebut, cukup untuk meluruhkan gigi dan tulang bersamaan dengan berjalannya waktu. Tubuh kita berhenti membangun tulang setelah usia 30 tahun, dan mulai luluh dengan persentasi $8-18 \%$ tiap tahunnya sesuai dengan tingkat keasaman yang kita konsumsi (persentasi keasaman tidak didasarkan pada rasa makanan, tetapi pada persentasi kandungan Potassium, Chlor, Magnesium dan senyawa-senyawa fosfor yang lain).

\section{KESIMPULAN DAN SARAN}

\section{Kesimpulan}

Hasil penelitian tentang pengaruh mengkonsumsi soft drink terhadap $\mathrm{pH}$ saliva dan angka
DMF-T pada siswa/I kelas XI IPA MAN 2 Model Medan adalah semakin banyak frekuensi minum soft drink maka semakin rendah angka $\mathrm{pH}$ saliva dan semakin tinggi frekuensi minum soft drink maka semakin rendah angka DMF-T di dukung dengan kebiasaan siswa/I yang meminum soft drink pada istirahat atau bersantai, dan tidak berkumur-kumur setelah minum soft drink tersebut.

Dari 32 orang siswa/I yang diteliti maka terdapat 6 orang siswa/I yang tidak terlalu sering mengkonsumsi soft drink dan dilihat dari persentase DMF-T yaitu 18,8\% maka dikategorikan baik. Adapun kategori buruk dilihat dari 26 siswa/I yang sering meminum soft drink dengan persentase DMF-T 81,3\% .

\section{Saran}

Sesuai dengan hasil penelitian yang telah dilakukan maka peneliti memberikan saran sebagai berikut :

1. Kepada siswa/I diharapkan dapat mengurangi minum coca cola agar tingkat terjadinya karies itu lebih sedikit.

2. Kepada siswa/I diharapkan agar setelah meminum coca cola agar berkumur-kumur atau banyak minum air putih, dan disarankan agar menganti coca cola dengan minuman ringan lain yang tidak mengandung karbonasi.

3. Kepada siswa/I di harapkan melakukan kontrol rutin ke balai pengobatan gigi

\section{DAFTAR PUSTAKA}

Ali, Mohammad., 2004. Psikologi Remaja.Bumi Aksara.Jakarta.

KIDD, Edwina A. M., 1991. Dasar - dasar karies .EGC. Jakarta.

Hariyadi,Purwiyatno., 2009. Memproduksi pangan yang aman. Dian rakyat.Jakarta

Sukarjo., 2004.kimia fisika.Rineka cipta. Jakarta

Halim, Deddy Kurniawan., 2008. Psikologi Lingkungan Perkotaan.Bumi Aksara.Jakarta.

Machfoedz, ircham., 2008. Menjaga kesehatan gigi dan mulut anak - anak dan ibu hamil .Fitramaya.Yogyakarta.

Sastrohamidjojo, Hardjono., 2010.Kimia Dasar.Gadjah mada. Yogyakarta.

http://www.medicalera.com/3/16355?thread=16355

http://m13ke.wordpress.com/2008/11/25/pengertiandan-fungsi-saliva/

http://klikdokter.com/minuman-mengandung-kafeinlebih-disukai-remaja\#

http://www.tempo.com/Konsumsi-Minuman-

Berkarbonasi-di-Indonesia-Rendah 